\title{
HAK DESAIN INDUSTRI DAN PERKEMBANGAN DESAIN INDUSTRI YANG ADA DI INDONESIA
}

\author{
DONI WINATA \\ 165100085, HAKI 785567889 \\ Fakultas Komputer \\ doniwinata.student@umitra.ac.id
}

\begin{abstract}
Sejalan dengan berkembangnya pertumbuhan ekonomi maka berkembang pula kehidupan di bidang Ilmu Pengetahuan dan Teknologi terutama pada sektor industri dan perdagangan. Dimana dari sektor industri itulah berbagai produk yang beranekaragam dihasilkan dengan menggunakan teknologi-teknologi yang cangggih dan modern. Yang mana hal tersebut dipersiapkan untuk menghadapi persaingan yang lebih berkompeten dalam era globalisasi. Dalam menghadapi persaingan tersebut sekarang ini diharapkan pertumbuhan ekonomi sangat memerlukan atau tidak mengesampingkan Ilmu Pengetahuan dan Teknologi. Karena Ilmu Pengetahuan dan Teknologi adalah satu faktor yang dominan dalam memenangkan persaingan dengan menggunakan keunggulan berupa kemampuan Ilmu Pengetahuan dan Teknologi, yang sangat berkaitan dengan bidang kekayaan intelektual.
\end{abstract}

Didalam bidang milik intelektual (Intelektual Property), yang khusus berkenaan dengan Ilmu Pengetahuan dan diterapkan dalam industri. Dimana pengetahuan dibidang ini sering disebut sebagai Hak Atas Kekayaan Industri (HAKI) yang dibagi menjadi lima bagian yaitu Paten, Merk, Desain Industri, Rahasia Dagang, dan Desain Tata Letak Sirkuit Terpadu. Disini saya akan membahas Hak Desain Industri Dan Perkembangan Desain Industri Yang Ada Di Indonesia.

Kata Kunci : Hak Desain Industri Dan Perkembangan Desain Industri Yang Ada Di Indonesia. 


\section{A. INTRODUCTION}

\section{HAK DESAIN INDUSTRI DAN PERKEMBANGAN DESAIN INDUSTRI YANG ADA DI INDONESIA}

Hukum di Indonesia merupakan campuran dari sistem hukum Eropa, hukum Agama dan hukum Adat. Sebagian besar sistem yang dianut, baik perdata maupun pidana, berbasis pada hukum Eropa kontinental, khususnya dari Belanda karena aspek sejarah masa lalu Indonesia yang merupakan wilayah jajahan dengan sebutan Hindia Belanda (Nederlandsch-Indie). Hukum Agama, karena sebagian besar masyarakat Indonesia menganut Islam, maka dominasi hukum atau Syari'at Islam lebih banyak terutama di bidang perkawinan, kekeluargaan dan warisan. Selain itu, di Indonesia juga berlaku sistem hukum Adat, yang merupakan penerusan dari aturanaturan setempat dari masyarakat dan budaya-budaya yang ada di wilayah Nusantara.

Dengan itu Hak Atas Kekayaaan Intelektual menjadi sangat penting, dikarenakan Hak Atas Kekayaaan Intelektual merupakan sesuatu Undang-undang yang dibuat untuk melindungi mengenai bidang-bidang yang bersangkutan dengan kekayaan intelektual serta untuk menghindari kemungkinan pemalsuan atau persaingan yang curang. Dengan adanya persaingan tersebut maka Hak Atas Kekayaaan Intelektual mempunyai peranan yang sangat penting untuk melindungi agar pemalsuan itu tidak terjadi dan Hak Atas Kekayaan Intelektual mempunyai kaitan yang sangat erat terhadap Ilmu Pengetahuan dan Teknologi maupun Ekonomi. Disebabkan Hak Atas Kekayaan Intelektual merupakan hak yang berasal dari hasil kegiatan kreatif suatu kemampuan daya pikir manusia yang di ekspresikan dalam berbagai bentuk yang memiliki atau mempunyai manfaat dan berguna dalam kehidupan manusia, yang artinya bahwa Hak Atas Kekayaaan Intelektual adalah suatu bentuk kekayaan bagi pemiliknya dan dari kepemilikannya itulah seorang mendapat keuntungan. Sehingga dengan hasil karya yang diciptakan itu akan mempunyai peranan penting bagi ekonomi serta Ilmu Pengetahuan dan Teknologi.

Dalam perkembangan perindustrian untuk menciptakan produk industri memerlukan rancangan model sebuah produk yang sering disebut desain industri dalam mengeluarkan produk tersebut dipasaran. Dan untuk melindungi desain industri ini maka diperlukan pengaturan tersendiri dalam Undang-Undang yang bersangkutan dengan desain industri tersebut yaitu dalam Undang-Undang Nomer. 31 tahun 2000.

\section{Desain Industri}

Menurut Undang-Undang Desain Industri No. 31 Tahun 2000 BAB I Ketentuan Umum Pasal 1 ayat (1) yang menyatakan: "Desain industri adalah suatu kreasi tentang bentuk, konfigurasi atau komposisi garis atau warna, atau garis dan warna, atau gabungan daripadanya yang berbentuk tiga dimensi atau dua dimensi yang memberikan kesan estetis dan dapat diwujudkan dalam pola tiga dimensi atau dua dimensi yang memberikan kesan estetis serta dapat dipakai untuk 
menghasilkan suatu produk, barang, komoditas industri, kerajinan tangan." Dari pengertian ini tampak bahwa salah satu yang disebut dengan desain industri itu adalah suatu kreasi bentuk, konfigurasi dan komposisi garis atau warna yang memberikan kesan estetis dan dapat dipakai untuk menghasilkan kerajinan tangan. Jelaslah, bahwa desain industri yang dihasilkan oleh pengrajin sebenarnya masuk dalam cakupan desain industri sebagaimana yang dirumuskan dalam UU Desain Industri. Ketika desain industri yang dihasilkan oleh pengrajin, maka patutlah untuk diberikan perlindungan hukum. Perlindungan hukum diberikan agar desain industri yang dihasilkan pengrajin tidak ditiru atau dimanfaatkan oleh pihak lain yang tidak berhak. Untuk desain industri yang dapat dilindungi hendaknya desain industri tersebut memenuhi beberapa kriteria. Kriteria yang dimaksudkan meliputi pada: Pertama, desain industri tersebut baru. Artinya, tidak sama dengan pengungkapan yang telah ada sebelumnya; Kedua, Tidak bertentangan dengan moralitas/kesusilaan; Ketiga, merupakan satu desain industri / beberapa desain industri yang merupakan satu kesatuan desain industri yang memiliki kelas yang sama dan; Keempat, desain industri yang didaftarkan tidak ditarik kembali permohonannya.

Apabila keempat kriteria ini telah dipenuhi, maka desain industri dapat didaftarkan. Konsekuensi dari pendaftaran desain industri, maka desain industri diharapkan akan mendapatkan perlindungan hukum. Perlindungan hukum atas desain industri diberikan terhitung sejak tanggal penerimaan. Jangka waktu perlindungan yang diberikan oleh UU Desain Industri adalah untuk jangka waktu 10 (sepuluh) tahun.

\section{Hak Desain Industri}

Apabila Pendesain / pengrajin mengajukan permohonan pendaftaran ia akan mendapatkan hak desain industri sekaligus sebagai pemegang hak desain industri. Hak desain industri adalah hak eksklusif yang diberikan oleh negara Republik Indonesia kepada pendesain (pengrajin) atas hasil kreasinya untuk selama waktu tertentu melaksanakan sendiri, atau memberikan persetujuannya kepada pihak lain untuk melaksanakan hak tersebut.

\section{B. CONTENT}

\section{Ruang Lingkup}

Terbitnya UU mengenai Desain Industri memang tergolong baru - UU Nomor 31 Tahun 2000 yang berlaku sejak 20 Desember 2000. Pendaftarannya sendiri baru dimulai pada 16 Juni 2001. Tak heran, bila desain industri kalah beken dibandingkan Hak Cipta, Paten atau Merek. Padahal desain bagi masyarakat menjadi indikator akan nilai sebuah produk. Lihat saja, bagaimana desain telepon selular, mobil, motor, produk elektronik atau produk lain berubah demikian cepat. Dengan desain yang semakin menarik maka nilai sebuah produk ikut terdongkrak.

Menurut UU desain industri pasal 1 ayat (2) menyatakan : " Pendesain adalah seorang atau beberapa orang 
yang menghasilkan Desain Industri". Hak Desain Industri diberikan untuk Desain Industri yang baru. Desain Industri dianggap baru apabila pada Tanggal Penerimaan, Desain Industri tersebut tidak sama dengan pengungkapan yang telah ada sebelumnya. Suatu Desain Industri tidak dianggap telah diumumkan apabila dalam jangka waktu paling lama 6 (enam) bulan sebelum Tanggal Penerimaannya, Desain Industri tersebut telah dipertunjukkan dalam suatu pameran nasional ataupun international di Indonesia atau di luar negeri yang resmi atau diakui sebagai resmi; atau telah digunakan di Indonesia oleh Pendesain dalam rangka percobaan dengan tujuan pendidikan, penelitian, atau pengembangan.

Berdasarkan pada ketentuan Pasal 9 UU Desain industri ditegaskan bahwa hak eksklusif yang dimiliki oleh pemegang hak desain industri mencakup pada: Pertama, hak untuk melaksanakan hak desain industri yang dimilikinya; dan Kedua, hak untuk melarang orang lain yang tanpa persetujuannya membuat, memakai, menjual, mengimpor, mengekspor, dan/atau mengedarkan barang yang diberi hak desain industri. Hal yang harus diketahui meskipun pemegang hak desain industri mempunyai hak eksklusif bukanlah berarti tidak ada pembatasan. Sesungguhnya ada pembatasan yang diberikan oleh UU Desain Industri. Pembatasan itu terletak tatkala desain industri yang telah terdaftar tersebut dipakai untuk kepentingan penelitian dan pendidikan sepanjang tidak merugikan kepentingan yang wajar dari pemegang hak desain industri.
Perlindungan terhadap Hak desain Industri diberikan untuk jangka waktu 10 (sepuluh) tahun terhitung sejak Tanggal Penerimaan.

\section{Perlindungan Terhadap Desain Industri}

Dalam perlindungan atas hak desain industri ini akan lebih memudahkan dalam melakukan sosialisasi kepada kalangan perusahaan dan pendesain dalam pemasaran sebuah produk kemasyarakat. Karena dalam realitanya atau kenyataannya yang terjadi dalam masyarakat adalah mengenai kesadaran masyarakat khususnya perusahaan dan pendesain terhadap pemahaman desain industri yang masih sangat rendah yaitu dalam prakteknya pengusaha tidak atau belum mendaftarkan desain industri barunya dari produk barang tersebut yang dimilikinya, dimana produk itu akan dipasarkan. Sehingga ada persaingan yang curang dengan membuat, memakai, menjual, mengimpor, mengekspor dan/atau mengedarkan barang yang diproduksi, dimana barang tersebut sudah diberi hak desain industri.

Dengan demikian obyek desain adalah barang atau komoditi yang merupakan desain yang digunakan dalam proses industri, karena itu desain industri merupakan karyaintelektual di bidang industri. Maka pemegang hak harus mendapatkan perlindungan atas desain industrinya agar pendesain tersebut akan menjadi lebih bersemangat untuk menciptakan inovasi desain-desain baru untuk barang yang diproduksioleh perusahaan yang bersangkutan. Dalam hubungan dengan industrialisasi adanya suatu pengaturan tentang desain industri ini mempunyai peranan 
yang sangat penting dalam mengacu pada perlindungan Hak Atas Kekayaan Intelektual. Dalam mengawasi persaingan dan perputaran ekonomi serta pemasaran, maka mutu danharga suatu produk adalah sangat penting. Demikian pula desain industri sangat penting sebagai salah satu unsur yang dapat membedakan satu produk dengan produk yang lainya.

Dengan mengingat hal-hal tersebut diatas dan berhubungan mengenai perlindungan hukum tentang desain industri yaitu untuk menjamin perlindungan hak-hak pendesain dan menetapkan hak dan kewajibannya serta menjaga agar pihak yang tidak berhak tidak menyalahgunakan hak desain industri tersebut. Yang menjadi landasan bagi perlindungan yang efektif terhadap berbagai bentuk kecurangan dengan cara membuat, memakai, menjual, mengimpor, mengekspor, dan/atau mengedarkan barang itu yang sudah diberi hak desain industri yang telah dikenal secara luas.

Adapun prinsip pengaturannya adalah pengakuan kepemilikan atas karya intelektual yang memberikan kesan estetis dan dapat diproduksi secara berulang- ulang serta dapat menghasilkan suatu barang dalam bentuk tertentu yaitu berbentuk dua dimensi atau tiga dimensi. Dengan demikian desain industri dalam dunia industri dan perdagangan mempunyai peranan penting dalam meningkatkan pertumbuhan ekonomi. Dan disinilah desain industri harus lebih dipacu dan lebih ditingkatkan agar dapat menghadapi persaingan yang ada dalam dunia industri dan perdagangan. Hak Desain Industri tidak dapat diberikan apabila Hak Desain Industri tersebut bertentangan dengan peraturan perundang-undangan yang berlaku, ketertiban umum, agama, atau kesusilaan.

\section{Cara Pendaftaran}

Direktorat Jendral tidak akan memberikan hak desain industri apbila tidak ada permohonan atau pendaftaran dari pengrajian atau pendesain, karena sesuai denga pasal 10 UU Desain Industri yang mengatakan : " Hak Desain Industri diberikan atas dasar Permohonan". Permohonan harus diajukan secara tertulis dalam bahasa Indonesia ke Direktorat Jenderal.

Adapun cara untuk mendapatkan Hak Desain Industri pemohon dapat mengajukan permohonan ke DJHKI secara tertulis dengan mnggunakan bahasa indonesia dengan cara :

1) mengisi formulir permohonan yang memuat;

a. tanggal,dan tahun surat permohonan;

b. nama, alamat lengkap dan kewarganegaraan pendesaian;

c. nama, alamat lengkap dan kewarganegaraan pendesain

d. nama, alamat lengkap, dan kewarganegaraan pemohon; nama negara dan tanggal penerimaan permohonan pertama kali dalam hal permohonan permohonan diajukan dengan hak prioritas.

2) Permohonan ditandatangani oleh pemohon atau kuasanya 
3) Dalam hal permohonan diajukan secara bersama-sama oleh lebih dari satu pemohon, permohonan tersebut ditandatangani oleh satu pemohon dengan dilampiri surat persetujuan secara tertulis dari pemohon lainnya

4) Dalam hal permohonan diajukan oleh bukan pendesain, permohonan harus dilengkapi dengan bukti yang cukup bahwa pemohon berhk atas desain industri yang bersangkutan yaitu membawa contoh fisik atau gambar atau foto dan uraian dari Desain Industri yang dimohonkan pendaftarannya.

5) Membayar biaya permohonan

Berdasarkan undang-undang Desain Industri pasal 45 yang mengatur tentang biaya untuk setiap pengajuan Permohonan, pengajuan keberatan atas Permohonan, permintaan petikan Daftar Umum Desain Industri , permintaan dokumen prioritas Desain Industri, permintaan salinan Sertifikat Desain Industri, pencatatan pengalihan hak, pencatatan surat perjanjian Lisensi, serta permintaan lain yang ditentukan dalam Undangundang ini dikenai biaya yang jumlahnya ditetapkan dengan Peraturan Pemerintah. Dalam PP Nomor 50 Tahun 2001, ada biaya khusus yang diberikan untuk UKM, pelajar atau mahasiswa dalam

$$
\begin{aligned}
& \text { mendaftarkan desainnya. } \\
& \text { Kelompok ini mendapat } \\
& \text { keringanan } 50 \text { persen dari Rp } \\
& 600.000 \text { setiap kali } \\
& \text { pendaftaran. }
\end{aligned}
$$

\section{Pengalihan Hak Desain Industri}

Menurut UU Desain Industri Pasal 31, hak desain industri dapat dialihkan dengan cara: pewarisan; hibah; wasiat; perjanjian tertulis; atau sebab-sebab lain yang dibenarkan oleh peraturan perundang-undangan.

Segala bentuk pengalihan Hak Desain Industri akan dicatat dalam Daftar Umum Desain Industri pada Direktorat Jenderal dengan membayar biaya sebagaimana diatur dalam Undangundang ini. Pengalihan Hak Desain Industri harus disertai dengan dokumen tentang pengalihan hak.

Pengalihan Hak Desain Industri yang tidak dicatatkan dalam Daftar Umum Desain Industri tidak berakibat hukum pada pihak ketiga. Pengalihan Hak Desain Industri akan diumumkan dalam Berita Resmi Desain Industri. Meskipun sudah dialihkan hak desainnya, tapi menurut UU Desain Industri pasal 32 dijelaskan bahwa Pengalihan Hak Desain Industri tidak menghilangkan hak Pendesain untuk tetap dicantumkan nama dan identitasnya, baik dalam Sertifikat Desain Industri, Berita Resmi Desain Industri, maupun dalam Daftar Umum Desain Industri. 


\section{CONCLUSION}

Hak desain industri adalah hak eksklusif yang diberikan oleh negara Republik Indonesia kepada pendesain (pengrajin) atas hasil kreasinya untuk selama waktu tertentu melaksanakan sendiri, atau memberikan persetujuannya kepada pihak lain untuk melaksanakan hak tersebut. Dasar hukum desain industri yaitu Undang-undang Nomor 31 Tahun 2000 tentang Desain Industri. Hak Desain Industri tidak dapat diberikan apabila Hak Desain Industri tersebut bertentangan dengan peraturan perundang-undangan yang berlaku, ketertiban umum, agama, atau kesusilaan.

Sanksi atas pelanggaran Hak desain industri di atur dalam UU Desain Industri pasal 54 yang menyebutkan bahwa dikenakan sanksi dengan pidana penjara paling lama 4 (empat) tahun dan/atau denda paling banyak Rp. 300.000.000,00 (tiga ratus juta rupiah).

Desain Industri terdaftar dapat dibatalkan oleh Direktorat Jenderal atas permintaan tertulis yang diajukan oleh pemegang Hak Desain Industri. Pembatalan Hak Desain Industri tidak dapat dilakukan apabila penerima Lisensi Hak Desain Industri yang tercatat dalam Daftar Umum Desain Industri tidak memberikan persetujuan secara tertulis, yang dilampirkan pada permohonan pembatalan pendaftaran tersebut.

\section{DISCUSSION}

\section{Pembatalan Pendaftaran Desain Industri}

Sesuai dengan ketentuan Undangundang Desain Industri pasal 37 bahwa Desain Industri terdaftar dapat dibatalkan oleh Direktorat Jenderal atas permintaan tertulis yang diajukan oleh pemegang Hak Desain Industri. Pembatalan Hak Desain Industri tidak dapat dilakukan apabila penerima Lisensi Hak Desain Industri yang tercatat dalam Daftar Umum Desain Industri tidak memberikan persetujuan secara tertulis, yang dilampirkan pada permohonan pembatalan pendaftaran tersebut. Kemudian keputusan pembatalan Hak Desain Industri diberitahukan secara tertulis oleh Direktorat Jenderal kepada:

1) pemegang Hak Desain Industri.

2) pemegang Lisensi jika telah dilisensikan sesuai dengan catatan dalam Daftar Umum Desain Industri.

3) Pihak yang mengajukan pembatalan dengan menyebutkan bahwa Hak Desain Industri yang telah diberikan dinyatakan tidak berlaku lagi terhitung sejak tanggal keputusan pembatalan. Keputusan pembatalan pendaftaran nantinya akan dicatatkan dalam Daftar Umum Desain Industri dan diumumkan dalam Berita Resmi Desain Industri. 


\section{E. REFERENCE}

[1] O. M. Febriani and A. S. Putra, "Sistem Informasi Monitoring Inventori Barang Pada Balai Riset Standardisasi Industri Bandar Lampung," J. Inform., vol. 13, no. 1, pp. 90-98, 2014.

[2] A. S. Putra, "Paperplain: Execution Fundamental Create Application With Borland Delphi 7.0 University Of Mitra Indonesia," 2018.

[3] A. S. Putra, "2018 Artikel Struktur Data, Audit Dan Jaringan Komputer," 2018.

[4] A. S. Putra, "ALIAS MANAGER USED IN DATABASE DESKTOP STUDI CASE DB DEMOS."

[5] A. S. Putra, "COMPREHENSIVE SET OF PROFESSIONAL FOR DISTRIBUTE COMPUTING."

[6] A. S. Putra, "DATA ORIENTED RECOGNITION IN BORLAND DELPHI 7.0."

[7] A. S. Putra, "EMBARCADERO DELPHI XE 2 IN GPUPOWERED FIREMONKEY APPLICATION."

[8] A. S. Putra, "HAK ATAS KEKAYAAN INTELEKTUAL DALAM DUNIA TEKNOLOGY BERBASIS REVOLUSI INDUSTRI 4.0."

[9] A. S. Putra, "IMPLEMENTASI PERATURAN PERUNDANGAN UU. NO 31 TAHUN 2000 TENTANG DESAIN INDUSTRI BERBASIS INFORMATION TECHNOLOGY."

[10]
"IMPLEMENTATION OF PARADOX DBASE."

A. S. Putra, "IMPLEMENTATION OF TRADE SECRET CASE STUDY SAMSUNG MOBILE PHONE."

[12] A. S. Putra, "IMPLEMENTATION

PATENT FOR APPLICATION WEB BASED CASE STUDI WWW. PUBLIKLAMPUNG. COM."

[13] Putra "IMPLEMENTATION SYSTEM FIRST TO INVENT IN DIGITALLY INDUSTRY."

[14] A. S. Putra, "MANUAL REPORT \& INTEGRATED DEVELOPMENT

ENVIRONMENT BORLAND DELPHI 7.0."

[15] A. S. Putra, "PATENT AS RELEVAN SUPPORT RESEARCH."

[16] A. S. Putra, "PATENT FOR RESEARCH STUDY CASE OF APPLE. Inc."

[17] A. S. Putra, "PATENT PROTECTION FOR APPLICATION INVENT."

[18] A. S. Putra, "QUICK REPORT IN PROPERTY PROGRAMMING."

[19] A. S. Putra, "REVIEW CIRCUIT LAYOUT COMPONENT

REQUIREMENT ON ASUS NOTEBOOK."

[20] A. S. Putra, "REVIEW TRADEMARK PATENT FOR INDUSTRIAL TECHNOLOGY BASED 4.0."

[21] A. S. Putra, "TOOLBAR COMPONENT PALLETTE IN 
OBJECT

ORIENTED

PROGRAMMING."

[22] A. S. Putra, "WORKING DIRECTORY SET FOR PARADOX 7."

[23] A. S. Putra, "ZQUERY

IMPLEMENTED

PROGRAMMING

STUDI

CASE PT. BANK BCA Tbk."

[24] A. S. Putra, D. R. Aryanti, and I. Hartati, "Metode SAW (Simple Additive Weighting) sebagai Sistem Pendukung Keputusan Guru Berprestasi (Studi Kasus: SMK Global Surya)," in Prosiding Seminar Nasional Darmajaya, 2018, vol. 1, no. 1, pp. 85-97.

[25] A. S. Putra and O. M. Febriani, "Knowledge Management Online Application in PDAM Lampung Province," in Prosiding International conference on Information Technology and Business (ICITB), 2018, pp. 181-187.

[26] A. S. Putra, O. M. Febriani, and B. Bachry, "Implementasi Genetic Fuzzy System Untuk Mengidentifikasi Hasil Curian Kendaraan Bermotor Di Polda Lampung," SIMADA (Jurnal Sist. Inf. dan Manaj. Basis Data), vol. 1, no. 1, pp. 21-30, 2018.

[27] A. S. Putra, H. Sukri, and K. Zuhri, "Sistem Monitoring Realtime Jaringan Irigasi Desa (JIDES) Dengan Konsep Jaringan Sensor Nirkabel," IJEIS (Indonesian J. Electron. Instrum. Syst., vol. 8, no. 2, pp. 221-232.

[28] D. P. Sari, O. M. Febriani, and
A. S. Putra, "Perancangan Sistem Informasi SDM Berprestasi pada SD Global Surya," in Prosiding Seminar Nasional Darmajaya, 2018, vol. 1, no. 1, pp. 289-294. 